\title{
Endothelial cell-derived signals in liver development and regeneration
}

\author{
Eckhard Lammert ${ }^{1,2^{*}}$, Jennifer Axnick', Tobias Buschmann ${ }^{1}$ \\ From 1st International Conference of Collaborative Research Center 974: Liver Damage and Regeneration \\ Düsseldorf, Germany. 15-16 November 2013
}

The liver harbors a specialized capillary bed. It is characterized by Lyve-1 and VEGFR3 expression, low CD31 and $\mathrm{vWF}$ expression and lack of CD34 expression [1], Moreover, the basement membrane is discontinuous, and liver sinusoidal endothelial cells are adjacent to a discontinuous basement membrane. Finally, the blood flow through liver sinusoidal capillaries is slow compared to many other organs. Besides the role of hepatic capillary beds in exchange of substances and gases between liver and blood, the endothelium of the liver is required for both liver development [2,3] and liver regeneration [4]. Interestingly, liver regeneration seems to be similar to liver development in that endothelial signals seem to be required during both processes. In the regenerating liver, it was shown that so-called angiocrine signals are needed and involved in discriminating between liver regeneration and liver fibrosis $[4,5]$.

As a model for liver regeneration in mice, a $2 / 3$ rd partial hepatectomy is normally performed. Importantly, the liver starts to divide and grow, and within a week the original liver cell mass is restored. Therefore, signals are needed to turn on and off liver regeneration. Previously, Michalopoulos and colleagues have proposed that after PHx three times more blood has to pass the liver when it is reduced to one-third of its original mass based on simple mathematics [6]. To this end, we propose that this increase in blood volume relative to liver mass might turn on angiocrine signals via mechanotransduction (Buschmann, Axnick \& Lammert, unpublished data). To this end, we perform different measurements to determine changes in the endothelium, blood flow and blood volume during the course of liver regeneration.

\footnotetext{
* Correspondence: lammert@hhu.de

'Institute of Metabolic Physiology, Heinrich Heine University, 40225

Düsseldorf, Germany

Full list of author information is available at the end of the article
}

\section{Authors' details}

'Institute of Metabolic Physiology, Heinrich Heine University, 40225 Düsseldorf, Germany. ${ }^{2}$ Institute for Beta Cell Biology, German Diabetes Centre, 40225 Düsseldorf, Germany.

Published: 19 June 2014

\section{References}

1. Si-Tayeb K, Lemaigre FP, Duncan SA: Organogenesis and Development of the Liver. Dev Cell 2010, 18:175-89.

2. Matsumoto K, Yoshitomi H, Rossant J, Zaret KS: Liver Organogenesis promoted by endothelial cells prior to vascular function. Science 2001, 294:559-563.

3. Zaret KS: Regulatory phases of early liver development: paradigms of organogenesis. Nat Rev Genet 2002, 3:499-512.

4. Ding BS, Nolan DJ, Butler JM, James D, Babazadeh AO, Rosenwaks Z, Mittal V, Kobayashi H, Shido K, Lyden D, Sato TN, Rabbany SY, Rafii S: Inductive angiocrine signals from sinusoidal endothelium are required for liver regeneration. Nature 2010, 468:310-315.

5. Ding BS, Cao Z, Lis R, Nolan DJ, Guo P, Simons M, Penfold ME, Shido K, Rabbany SY, Rafii S: Divergent angiocrine signals from vascular niche balance liver regeneration and fibrosis. Nature 2014, 505:97-102.

6. Michalopoulos GK: Liver regeneration after partial hepatectomy: critical analysis of mechanistic dilemmas. Am J Pathol 2010, 176:2-13.

doi:10.1186/2047-783X-19-S1-S2

Cite this article as: Lammert et al:: Endothelial cell-derived signals in liver development and regeneration. European Journal of Medical Research 2014 19(Suppl 1):S2.

Submit your next manuscript to BioMed Central and take full advantage of:

- Convenient online submission

- Thorough peer review

- No space constraints or color figure charges

- Immediate publication on acceptance

- Inclusion in PubMed, CAS, Scopus and Google Scholar

- Research which is freely available for redistribution

Submit your manuscript at www.biomedcentral.com/submit 